\title{
L\&PM POCKET, A MAIOR COLEÇÃO DE LIVROS DE BOLSO DO BRASIL: UMA ANÁLISE DO CATÁLOGO
}

\author{
L\&PM POCKET, THE LARGEST COLLECTION OF PAPERBACKS IN BRAZIL: \\ AN ANALYSIS OF THEIR CATALOG
} L\&PM POCKET, LA MAYOR COLECCIÓN DE LIBROS DE BOLSILLO EN BRASIL:
UN ANÁLISIS DEL CATÁLOGO

\author{
William Wrighini de Souza \\ E-mail: wrighini@yahoo.com.br \\ Giulia Crippa \\ E-mail: giuliac@ffclrp.usp.br
}

\section{Resumo}

Por meio do catálogo 2012 da coleção L\&PM Pocket da editora L\&PM, pretende-se estratificar e analisar as características editoriais desta coleção, como a escolha das capas, apresentação dos elementos pré e pós-textuais e temas abordados. Discute-se a política de preços de venda assim como reflete sobre os públicos da L\&PM Pocket e livros de bolso em geral. Conclui-se que o catálogo é diversificado, apresenta títulos de qualidade reconhecida e tem perfil generalista, não abrangendo especialidades acadêmicas.

Palavras-chave: L\&PM Pocket. Catálogo. Livro de bolso.

\begin{abstract}
Using L\&PM's 2012 catalog, we intend to stratify and analyze the editorial features of L\&PM Pocket collection, such as their choice of covers, presentation of the pre- and post-textual elements, and subjects. We also discuss the policy of selling prices as well as we reflect on the public of L\&PM Pocket and paperbacks in general. We conclude that the catalog is diverse and offers titles widely recognized for their quality, but it does not cover academic specialties.
\end{abstract}

Keywords: L\&PM Pocket. Catalog. Paperbacks.

\section{Resumen}

A través del catálogo de 2012 de la colección L\&PM Pocket de la editorial L\&PM, se pretende estratificar y analizar las características editoriais de esta colección, como la elección de las portadas, la presentación de los elementos pre y post-textual y de los temas tratados. También se discute la política de precios de venta, así como una reflexión sobre el público de la L\&PM Pocket y de los libros de bolsillo en general. Llegamos a la conclusión de que el catálogo es diversa, generalista y cuenta con títulos de calidad, pero no cubre especialidades académicas.

Palabras clave: L\&PM Pocket. Catálogo. Libro de bolsillo. 


\section{Introdução}

Ao longo dos últimos anos, tempos presenciado a criação de diversas coleções de livros de bolso no Brasil. Apresentadas como iniciativas para a democratização do acesso ao livro, cada uma tem apostado em diferentes características e meios para atingir o objetivo proposto, em consonância com o perfil da editora publicadora. Entre elas, a principal coleção é a L\&PM Pocket, lançada em 1997 pela gaúcha L\&PM, alguns anos antes da maioria das opções atualmente disponível no mercado, sendo vista como um modelo pelas seguintes.

Luiz Schwarcz, proprietário, diretor e editor da Companhia das Letras, ao lançar sua coleção de bolso, a Companhia de Bolso, reconheceu o papel da L\&PM Pocket para o renascimento do livro de bolso no país na passagem do século XX para o XXI:

Historicamente, o livreiro não recepcionava bem o livro de bolso. Como os exemplares eram mais baratos ele não demonstrava interesse em receber margens menores por produto. A experiência da L\&PM mostra que isso mudou (SCHWARCZ apud MACHADO, 2005).

Ciente de sua relevância, este artigo pretende analisar o catálogo 2012 da L\&PM Pocket, apontando e discutindo as características editoriais da coleção, da escolha das capas aos temas abordados. Desta maneira, pretendemos ir além de análises que não consideram a coleção em sua completude nem em relação ao perfil da editora. A seguir, apresentamos tanto resultados numéricos/ estatísticos alcançados a partir da consulta ao catálogo online e impresso como as ponderações realizadas a partir da sistematização e estratificação dessas informações.

A L\&PM Pocket, da L\&PM, além de ser a maior coleção de livros de bolso do Brasil, com mais de 1.000 títulos em seu catálogo, é provavelmente a mais conhecida pelos brasileiros. Mesmo que muitos não se atentem ao nome da editora, seus livros estão expostos em centenas de livrarias, supermercados, bancas de jornal e até mesmo farmácias espalhados pelo país. Em displays oferecidos pela editora, muitos deles giratórios ${ }^{1}$, esses pequenos livros ocupam um lugar de destaque em seus locais de venda, apesar de, cada vez mais, precisarem dividir o espaço com novas coleções que surgem a cada ano nesse mercado em expansão.

Após dezenas de coleções de bolso malsucedidas ou de alcance limitado desde a década de 30 do século passado, a L\&PM conseguiu se consolidar com sua proposta e abriu o

1 A primeira editora a utilizar displays giratórios no Brasil foi a EBAL (Editora Brasil-América Ltda.), na década de 1940, sendo seguida pela filial da Hachette no país, pela Monterrey e pela Tecnoprint (LABANCA, 2009, p. 157). 
caminho para que outras grandes editoras criassem o seu próprio selo. Hoje, pela primeira vez em nossa história, é difícil encontrar uma expressiva editora brasileira que não possua um selo ou edições de pequeno formato e preço reduzido. Podemos citar a Companhia de Bolso, pela Companhia das Letras; BestBolso, pela Record; Saraiva de Bolso, pela Saraiva; Portátil, pela Cosac Naify; Globo de Bolso, pela Editora Globo, Ponto de Leitura, pela Alfaguara, entre outras.

Para melhor compreender o surgimento e crescimento dessa coleção, este artigo aborda as características descritivas/ físicas da L\&PM Pocket e como elas se relacionam com a política de preços da editora, as estratégias de marketing, os autores, gêneros, etc., evidenciando a relação entre as escolhas editoriais e o contexto socioeconômico e cultural no qual o livro é publicado e oferecido ao leitor. Por esta análise ter sido realizada em maio de 2013, o catálogo examinado foi o de 2012, disponível no site da L\&PM para consulta e download nessa data (L\&PM, 2012) 2 .

\section{Coleção L\&PM Pocket}

A L\&PM Editores foi fundada em 1974, por Ivan Pinheiro Machado e Paulo de Lima, para a publicação do livro de tirinhas Rango 1, do desenhista e cartunista Edgar Vasques. O objetivo dos jovens editores, na época com 22 anos, era editar quadrinhos, cartuns e reportagens (WILLER, 2008). A boa repercussão do primeiro livro permitiu que a editora publicasse outros títulos, a maioria crítica ao regime militar, provocando uma série de problemas para os editores, que eram repreendidos pelos militares e sofriam com a apreensão de obras pela polícia, como aconteceu com Memórias de um revolucionário, organizado por Hélio Silva.

Com sede em Porto Alegre, ainda na década de 1970, a L\&PM começou a publicar a produção do escritor Luis Fernando Veríssimo, que permaneceu na editora até 2001. Além do escrito gaúcho, seu catálogo ainda contou, ao longo das últimas décadas, com outros importantes nomes brasileiros, como Darcy Ribeiro, Moacyr Scliar, Ziraldo, Millôr Fernandes, Dalton Trevisan; e internacionais, como Woody Allen, Henry Miller, Vladimir Nabokov, Jorge Luis Borges e Stephen King (L\&PM, [2013?]b).

Simultaneamente, os editores sempre tiveram a preocupação de lançar obras que despertassem o interesse dos mais jovens. Sendo assim, durante as décadas de 1970 e 1980, incluindo períodos de forte repressão pela ditadura militar, produziram as coleções Rebeldes

\footnotetext{
${ }^{2}$ Endereço da página principal da L\&PM Editores: www.lpm.com.br 
\& Malditos, Universidade Livre, deram destaque à geração beat, com Jack Kerouac, Allen Ginsberg, William S. Burroughs, divulgaram Charles Bukowski no Brasil, entre outras iniciativas. Ivan Pinheiro e Paulo Lima, com pouca idade, inconformados com o regime, desejavam que a editora ou, pelos menos, grande parte dos seus títulos, representasse uma geração, uma postura de crítica perante aqueles anos difíceis (WILLER, 2008).

Mesmo sem se limitar a um gênero ou se especializar em um público, a L\&PM escolheu como política editorial uma postura de crítica social, de oposição ao governo militar, sendo um espaço para autores que defendiam/defendem ideais da esquerda. Em 2008, em uma entrevista a Claudio Willer (2008), Ivan Pinheiro Machado afirmou:

No caso da coleção POCKET nosso projeto inicial era formatar uma grande coleção que fosse, como eu gosto de chamar, "polifônica", ou seja, que abrigasse várias vozes. Hoje com quase 800 volumes, acho que conseguimos este objetivo, pois a coleção atinge vários públicos, sem ser filosoficamente contraditória.

Apesar do sucesso obtido nas décadas de 1970 e 1980, em meados da década de 1990, a editora passou por uma crise financeira que colocou em risco sua continuidade. Primeiro teve de enfrentar as limitações impostas pela inflação e juros altos. Depois, com uma forte entrada de capital estrangeiro no país, permitindo que editoras se expandissem a partir de investimentos internacionais, a concorrência aumentou ainda mais. Nesse momento, a L\&PM, que não trocou de proprietários, começou a encontrar maiores empecilhos para manter seus autores, assediados por grandes grupos (WILLER, 2008).

Como projeto para melhorar suas vendas e aumentar os lucros, os editores então criaram, em 1997, a coleção L\&PM Pocket, formada por livros de bolso. Entendemos que a coleção oferecia pelo menos três contribuições para a recuperação econômica da L\&PM: permitiria publicar vários títulos/autores consagrados sem pagar por direitos autorais, possibilitando uma diminuição dos gastos; seria uma das poucas coleções de bolso no país, pois as editoras não estavam investindo no segmento, o que garantiria pouca concorrência e, por último, criaria condições para uma reformulação do seu catálogo, atualizando capas, preços, criando séries para novos autores, etc. Nesse sentido, não podemos esquecer que vários dos títulos que fizeram sucesso nas décadas anteriores foram relançados em formato de bolso pela nova coleção.

Segundo a editora, a proposta da L\&PM Pocket se baseava em quatro princípios: "textos integrais, alta qualidade editorial e industrial, preços baixos e distribuição 'total', 
atingindo todo o Brasil” (L\&PM, [2013?]b). Deste modo, publicando quadrinhos, romances, contos, poesias, biografias, ensaios, a editora se disseminou pelo país, colocando suas edições tanto em livrarias tradicionais quanto em bancas de jornal, aeroportos, lojas, etc. Além disso, com cada vez mais títulos, várias séries dentro da coleção foram criadas, como a Encyclopaedia, a Plus, a Biografias e a Gastronomia.

A coleção "L\&PM Pocket" surge exatamente da falta de um best seller na editora, da presença de um catálogo de quase trinta anos com títulos cuja curva de vendas mostrava morte certa, de uma crise financeira e do desencanto na relação com os outros colegas editores (OLIVEIRA, 2002, p. $63)$.

Embora tenha a livraria como o principal canal de venda ao leitor (WILLER, 2008), além de, como quase toda editora hoje em dia, oferecer suas edições pela Internet através de cadeias de lojas/livrarias online, a L\&PM Pocket também conta com uma ampla rede de bancas de jornal que permite a divulgação dos livros mesmo em regiões afastadas dos grandes centros, a um público que não tem o costume de frequentar livrarias nem acessar a Internet. Em um país no qual a distribuição sempre foi vista como um empecilho para o crescimento do mercado editorial, conseguir utilizar bancas de jornal, livrarias físicas e Internet ao mesmo tempo é uma vantagem que poucas editoras têm à disposição. Para ampliar ainda mais o acesso, a partir de 2011, a L\&PM iniciou a digitalização do seu catálogo, incluindo os pockets.

Se o formato de bolso, com as suas características editoriais, já permite um menor preço de venda, o livro digital é ainda mais barato. Considerando que não é comum coleções de bolso serem também disponibilizadas em formato digital, podemos dizer que esta atitude da L\&PM foi mais uma inovação da editora. Aliás, nessa transformação, o próprio livro deixa de ser bolso, distanciando-se do seu conceito e mantendo apenas o preço mais acessível. Somente nos referimos a "livros de bolso que foram digitalizados" porque foi a partir do modelo impresso que o digital foi estabelecido.

Em 2012, a coleção alcançou os seus primeiros 1.000 títulos, divididos em séries que confirmam a variedade de temas e que a consolidam como "a maior coleção de livros de bolso do Brasil", como a própria editora divulga. A maior série é a Humor \& Quadrinhos (96 títulos - incluindo três mangás), que conta com os principais cartunistas nacionais, como Laerte, Glauco, Angeli, Maurício de Sousa, entre outros, e alguns dos principais internacionais, como Charles Schulz, Jim Davis e Scott Adams. Em 2011, a série lançou seus três primeiros 
mangás (Eles aparecem como uma série separada, mas, pelo pouca quantidade, inserimos na mesma dos quadrinhos). Dos 96 títulos, 94 custam entre $\mathrm{R} \$ 10,01$ e $\mathrm{R} \$ 15$. Apenas um título é vendido a $\mathrm{R} \$ 5$ e outro a $\mathrm{R} \$ 16$. A maioria das obras da série possui entre 100 e 150 páginas.

Publicar quadrinhos em formato de bolso acabou por ser uma proposta corajosa da coleção por duas razões. Primeira, muitos quadrinhos eram originalmente em cores e precisaram ser colocados em branco e preto para serem vendidos a baixo-custo. Segunda, alguns deles foram projetados para destacar e facilitar a visualização das imagens, sendo necessário adaptá-los a um novo formato. Deste modo, a visualização do conteúdo sofre transformações profundas e pode desagradar o leitor. No entanto, ao dar início a publicações de mangás a partir de 2011, a L\&PM mostrou que a série pode se diversificar ainda mais.

Se a série Humor \& Quadrinhos é a maior da coleção, duas séries são dedicadas a apenas um autor e são as que mais se destacam: Série Agatha Christie e Série Simenon. Com 57 títulos de acordo com o catálogo de 2012, a série Agatha Christie começou a ser publicada em 2007, com o título A noite das bruxas. As obras são oferecidas por valores que variam entre R \$ 18 e 20 e a maior parte dos títulos possuem entre 200 e 300 páginas.

Com o mesmo número de títulos em 2012, 57, a série Simenon foi lançada em 2004, com o título $O$ caso Saint-Fiacre, em parceria com a editora Nova Fronteira, que já o havia publicado. Em exclusividade pela L\&PM Pocket, o primeiro título foi Memórias de Maigret, em 2006, que ainda não havia sido traduzido no Brasil. Até o momento, todos os livros da série custam $\mathrm{R} \$ 18$ e a maioria possui entre 151 e 200 páginas.

Ainda em romances policiais, a L\&PM Pocket conta com 18 títulos de Arthur Conan Doyle, criador das aventuras de Sherlock Holmes, disponíveis no catálogo desde 1997, ano de início da coleção; cerca de 10 títulos de Raymond Chandler, autor também presente desde 1997, além de mais alguns autores e títulos isolados. Ao todo, o gênero representa pouco mais de $15 \%$ da coleção L\&PM Pocket, uma quantidade significativa considerando a diversidade de temas que a editora busca alcançar em seu catálogo.

Vários dos títulos policiais lançados pela L\&PM Pocket foram inicialmente publicados no Brasil pela Coleção Amarela, criada em 1931 pela Editora Globo para oferecer romances e novelas policiais, de crime, mistério e aventuras. No formato 13 x $19 \mathrm{~cm}$ e ao preço de cinco mil-réis a versão brochura e oito mil-réis a encadernada, os títulos da coleção não eram considerados de bolso por não serem tão pequenos quanto os das coleções Globo $(11 \times 16 \mathrm{~cm})$, Tucano $(12 \times 18,5 \mathrm{~cm})$ e Catavento $(12 \times 18,5 \mathrm{~cm})$ nem tão baratos como as 
demais. A coleção Globo, por exemplo, lançada dois anos depois, em 1933, vendia seus exemplares por três mil-réis e quinhentos. Contudo, eram vistos como acessíveis e alcançou um grande sucesso no Brasil, sendo a coleção mais duradoura e bem sucedida da editora ao publicar 156 títulos ao longo de 25 anos, com encerramento em 1956 (AMORIM, 1999, p. 75-77).

Egdar Wallace foi o autor mais publicado pela coleção Amarela, com 35 títulos ou 309.500 exemplares, seguido por Sax Rohmer, com 12 títulos ou 71.000 exemplares. Ambos não estão no catálogo L\&PM. Entretanto, Agatha Christie e Georges Simenon também exerceram um papel relevante na coleção da Editora Globo, ocupando as primeiras posições tanto em número de edições como de exemplares publicados, com 12 títulos ou 52.000 exemplares para Christie e cinco títulos ou 37.000 exemplares para Simenon. A maioria das edições contava com tiragem de cinco mil exemplares, com exceção das mais procuradas, como as obras de Wallace, que poderiam alcançar sete ou até dez mil (AMORIM, 1999, p.77$80)$.

Grande parte das capas desses romances policiais da L\&PM Pocket são adaptações de versões internacionais. As capas dos livros de Agatha Christie foram produzidas, originalmente, pelo capista David Wardler para a editora britânica HarperCollins. Em entrevista à L\&PM, David explica que sua inspiração foram os cartazes ferroviários e pôsteres undergrounds dos anos 1950 que faziam sucesso no Reino Unido. As capas, em design retrô, valorizam cores primárias e destacam o nome da autora na parte superior da imagem, imitando uma caligrafia manual, condizente com a sugestão de produção antiga (L\&PM, 2011).

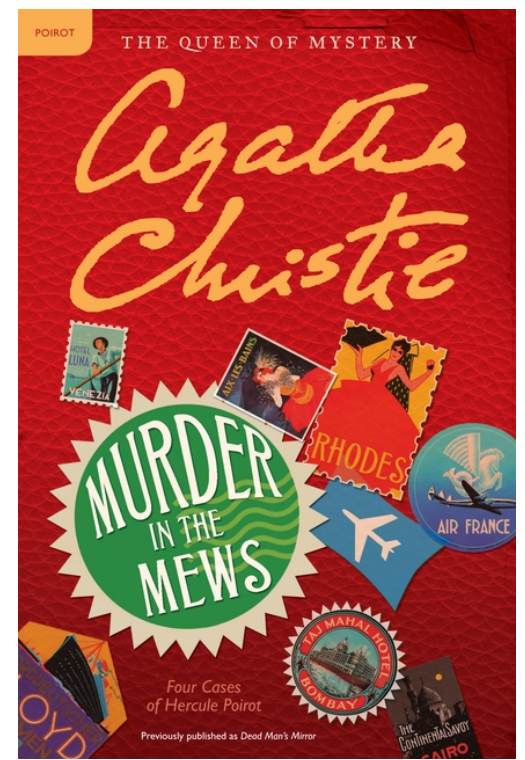

Fig. 1: Versão produzida para a HarperCollins.

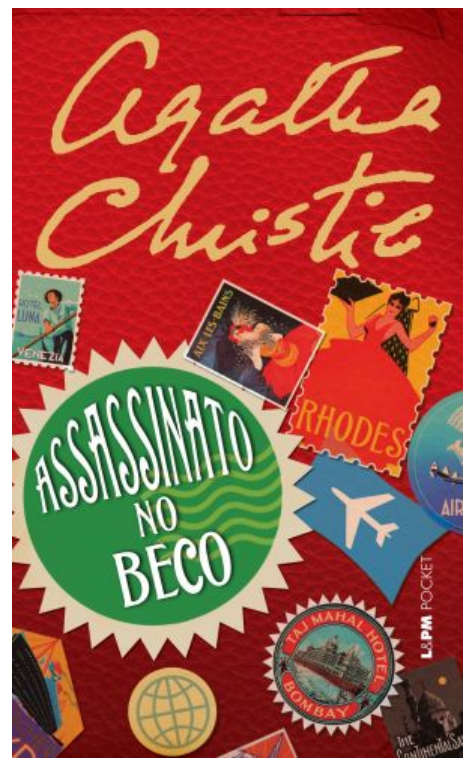

Fig 2: Adaptação brasileira, em formato mais curto, pela L\&PM 
As capas das obras de Simenon seguem a mesma estrutura dos títulos do autor lançados pela coleção francesa Le Livre de Poche. A partir de uma foto ao fundo, geralmente escura, sugestiva e com sombras que produzem um ar de mistério, suspeita, uma tira preta é inserida na parte superior da capa com o nome do personagem central da série, o detetive Maigret, em um tipo similar ao utilizado nas capas dos livros de Agatha Christie, ou seja, em cursivo, mais o título da obra e nome do autor em um tipo que remete a textos datilografados, como aqueles produzidos em delegacias e consultados por detetives como Maigret.

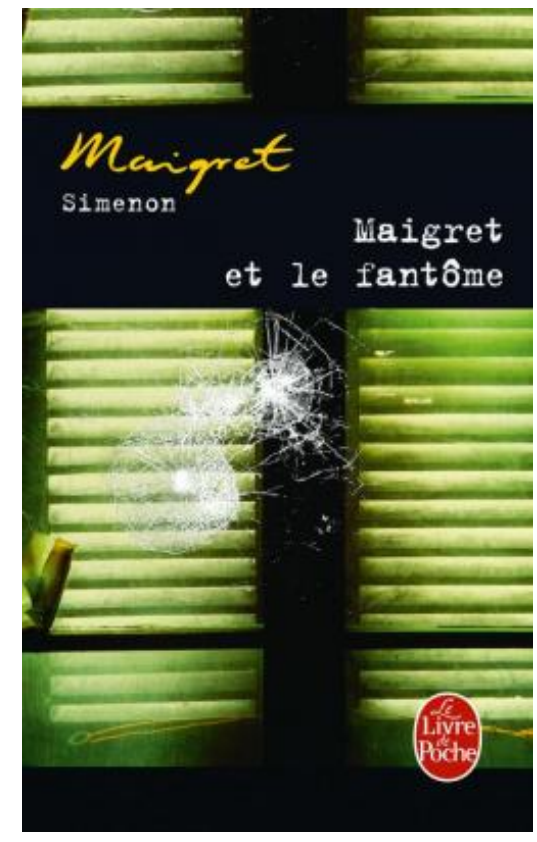

Fig. 3: Versão produzida para a Le Livre de Poche

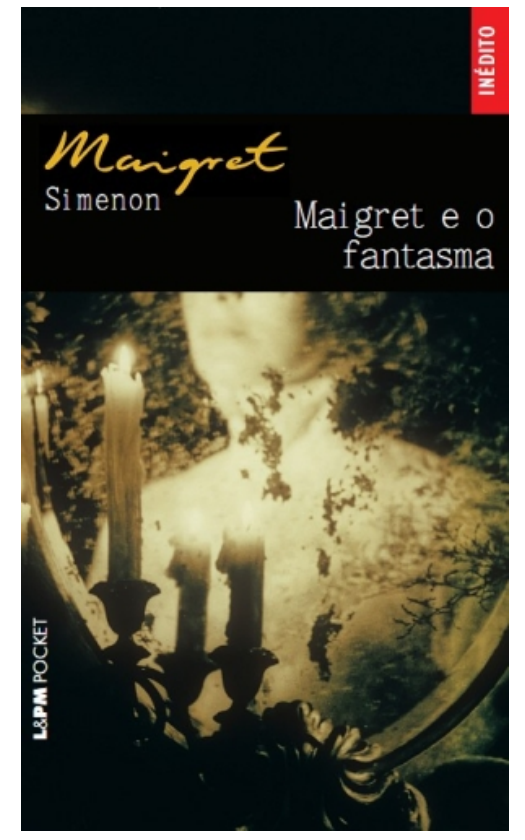

Fig. 4: Adaptação brasileira, em formato mais curto, pela L\&PM

Já as capas dos títulos de Ramond Chandler são adaptações dos modelos lançados pela Penguin no Reino Unido, com cores fortes, contrastantes, utilizando desenhos unidimensionais que facilitam a inserção dos títulos dentro da imagem central. Sem muitos detalhes, minimalistas, essas obras se destacam pela fonte grande e pelo jogo de cores que chama a atenção do leitor. 


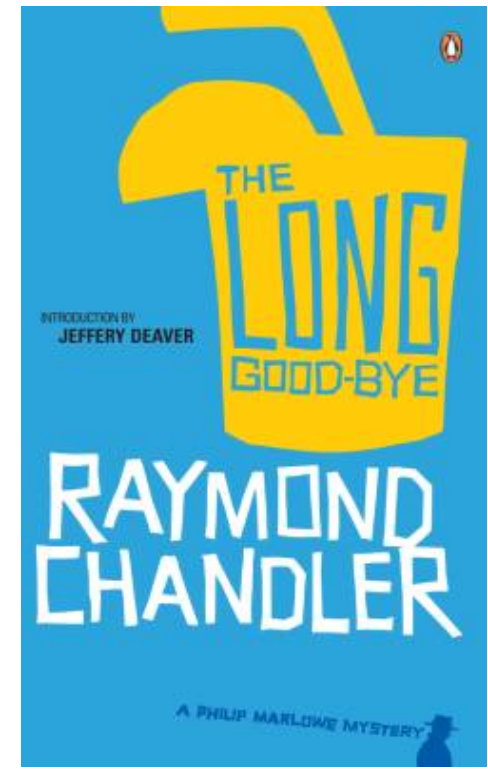

Fig. 5: Versão produzida para a Penguin UK

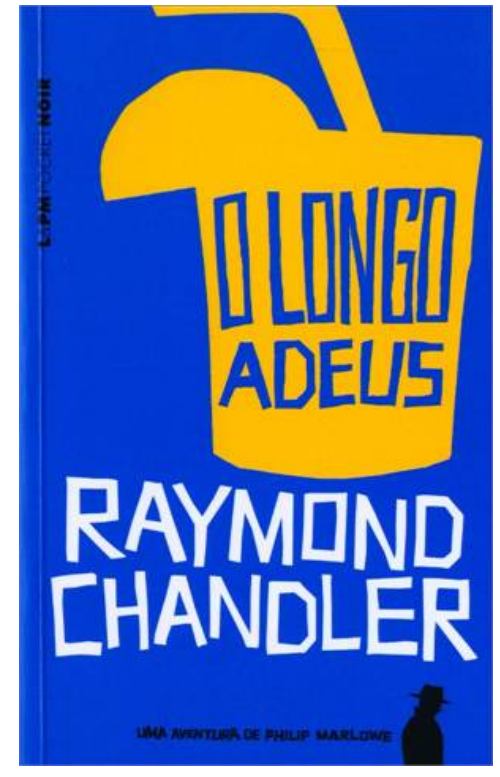

Fig. 6: Adaptação brasileira pela L\&PM

Os demais romances policiais estão divididos por diferentes séries, não possuindo um design comum.

O apelo de massa do romance policial explica, em parte, o espaço a ele destinado na coleção L\&PM Pocket. A primeira obra claramente do gênero foi Assassinatos na Rua Morgue (1841), de Edgar Allan Poe, também oferecida pelo catálogo de bolso da editora. Em um período de crescimento dos jornais, com seus folhetins e seção de faits divers, que evidenciavam a insegurança da população em face ao surgimento das grandes cidades industriais, o anseio por justiça, além da ampla aceitação dos ideais positivistas, esse gênero de ficção veio atender as expectativas das massas do século XIX (REIMÃO, 1983, p. 18).

Agatha Christie e Simenon exemplificam o modelo mais tradicional de romance policial, o romance de detetive ou de enigma (REIMÃO, 1983, p. 11). Basicamente, como aponta Todorov (1979, p. 96), esse tipo de romance é dividido em duas partes, com a história do crime na primeira e a história do inquérito na segunda. O final é a realização da justiça, quando o detetive soluciona o mistério. Com dezenas de títulos publicados, Agatha Christie e Simenon utilizaram essa estrutura base para alcançar milhares de leitores ao redor do mundo. Não há, no romance policial, longos trechos descritivos ou reflexivos que poderiam cansar o leitor mais afoito (BOILEAU; NARCEJAC, 1991, p. 39), mas uma sucessão de pistas e indícios capazes de criar reviravoltas que prendem a atenção e aumentam o anseio pelo desfecho do mistério. Desse modo, com um desenvolvimento narrativo e linguagem previamente conhecidos, o romance de detetive alcançou significativa aceitação, sendo presença constante em coleções de apelo popular. 
Outro tipo de romance policial contemplado pela L\&PM Pocket foi o romance noir, tendo Dashiell Hammett, seu criador, e Raymond Chandler como seus exponentes mais conhecidos. Foi a partir de 1925, na revista norte-americana Black Mask, que Hammett começou a publicar seus contos e romances e, posteriormente, Chandler iniciou sua carreira. Contudo, foi com o lançamento da Série Noire em 1945 na França que o estilo foi amplamente divulgado e consolidou seu público (REIMÃO, 1983, p. 51-52).

Ao contrário do romance de detetive, o romance noir não é otimista, conformista, não oferece a garantia da solução do crime nem a certeza de que o detetive sairá imune. Em um período de questionamento do racionalismo positivista e de crise nos Estados Unidos, o noir abriu espaço para a imoralidade e a anormalidade, apresentadas em uma linguagem coloquial, direta, com palavrões e gírias (REIMÃO, 1983, p. 54-55). O triunfo da justiça é substituto pela exposição do fracasso, pelo desencanto e desespero. Como explica Todorov (1979, p. 98), a clássica divisão entre parte do crime e parte do inquérito foi suprimida por narrativas mais imprevisíveis, com personagens humanizados, que precisam lidar com crimes e, talvez, solucioná-los, em ambientes sórdidos e de grande corrupção.

Entre os títulos de ficção, ainda se destacam as peças de Shakespeare. São as suas mais de 20 peças publicadas pela coleção que auxiliam a categoria Teatro ultrapassar os 5\% na divisão das obras da L\&PM Pocket por assunto. As peças, no formato da coleção, possuem entre 100 e 200 páginas, como exceção de Como gostais/ Conto de inverno, que conta com 256 páginas e oferece, em conjunto, as duas peças que formam o título do livro.

Como Shakespeare é um autor reconhecido e por seus títulos já terem sofrido diversas adaptações, seja para outras estruturas narrativas como para a divulgação no cinema e na TV, a série tem potencial para atrair um público leitor diversificado. Não é sem razão que uma das biografias da série Biografia é sobre Shakespeare, que as Obras escolhidas do autor foram editadas pelas Edições Ouro ${ }^{3}$ e que dois dos seus clássicos estão na série Neoleitores ${ }^{4}$. Talvez, já pensando nesta possibilidade de encontrar leitores além dos consumidores tradicionais de peças de teatro, as capas de vários exemplares, que não seguem um padrão em relação ao design, recorrem a um modelo já utilizado há décadas, principalmente entre os livros

\footnotetext{
${ }^{3}$ As Edições Ouro é uma série da L\&PM Editores não pertencente à coleção L\&PM Pocket. Criada em 2008, no formato $16 \times 23 \mathrm{~cm}$, sua proposta é publicar coletâneas de textos do mesmo autor ou do mesmo assunto. Até o momento, a série possui apenas 6 títulos, sendo o primeiro as Obras escolhidas de Shakespeare.

${ }^{4}$ A série Neoleitores foi lançada em 2010 e também não pertence à coleção L\&PM Pocket. A série é formada por clássicos da literatura nacional e internacional adaptados para a leitura por adultos em processo de alfabetização ou crianças. Todos os títulos são vendidos a R\$ 10, com exceção do livro do professor que é gratuito. Os exemplares possuem entre 48 páginas (o menor número) e 96 (o maior). Os dois livros de Shakespeare adaptados são Romeu e Julieta e Hamlet.
} 
populares norte-americanos, para aproximar o público da história e, de certa forma, explicála: a utilização de uma cena da narrativa como capa, acrescentando ao título um desenho que o complementa, que sugere o conteúdo da peça e auxilia o leitor na formação de representações.

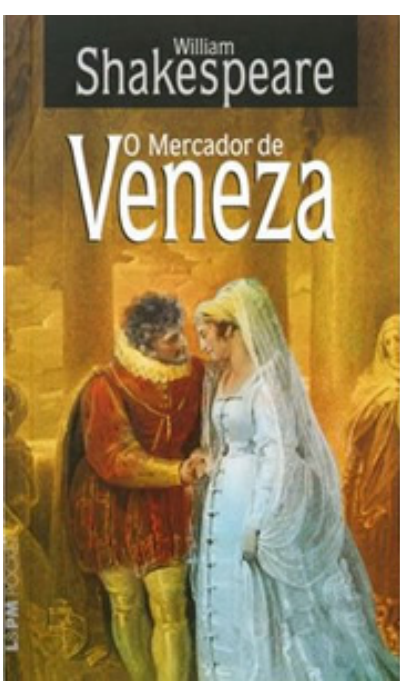

Fig. 7: O mercador de Veneza

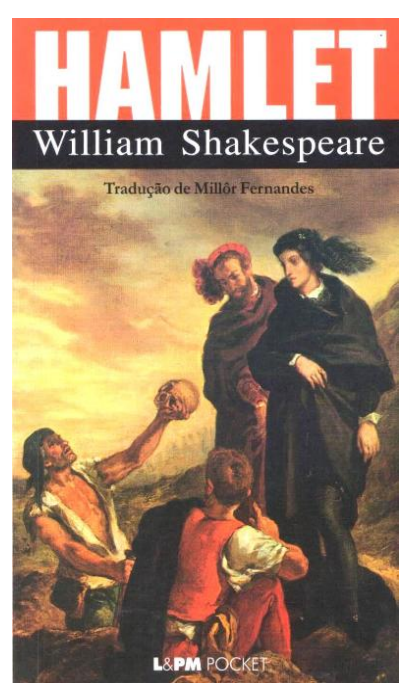

Fig. 8: Hamlet

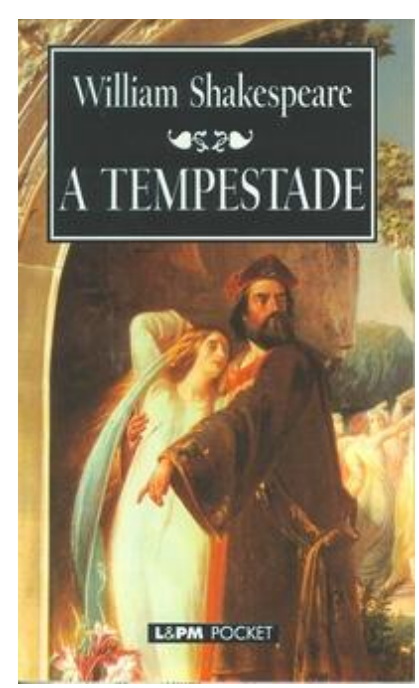

Fig. 9: A tempestade

Técnica similar, pouco utilizada pela L\&PM, mas muito comum em coleções nacionais e estrangeiras voltadas para um público heterogêneo, é a utilização de uma cena de filme na capa quando a obra foi adaptada para o cinema. Dessa maneira, além de conseguir aproveitar a visibilidade proporcionada por outro meio de comunicação, a editora se aproxima de pessoas pouco acostumadas a comprar livros, mas que assistiram/ se interessam pelo filme, assim como daquelas que não sabem que é uma adaptação e são informadas pela referência cinematográfica. 


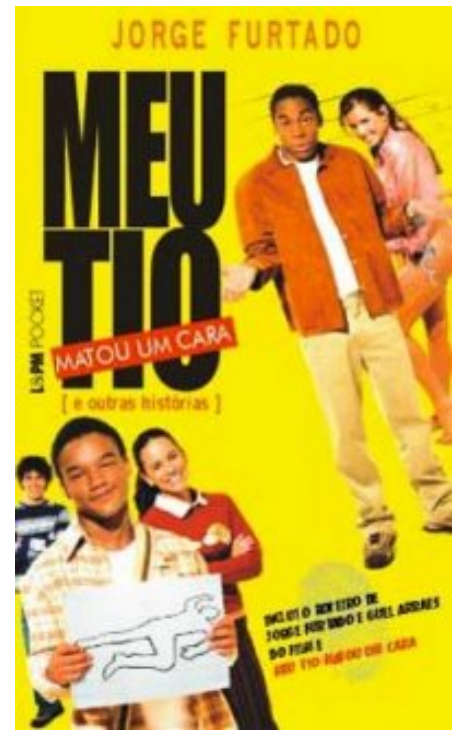

Fig. 10: Meu tio matou um cara

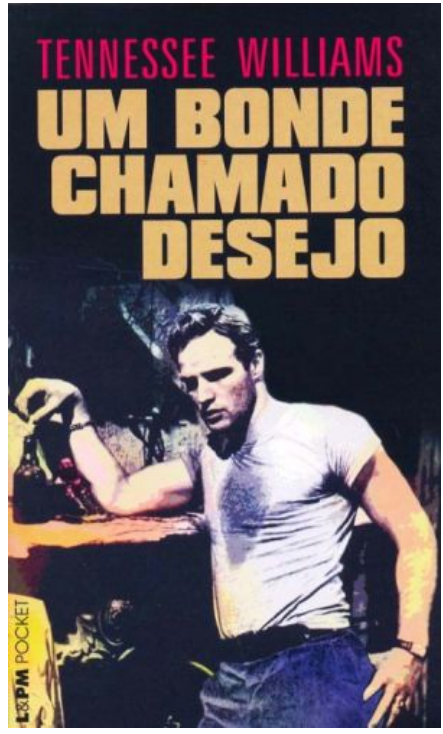

Fig. 11: Um bonde chamado desejo

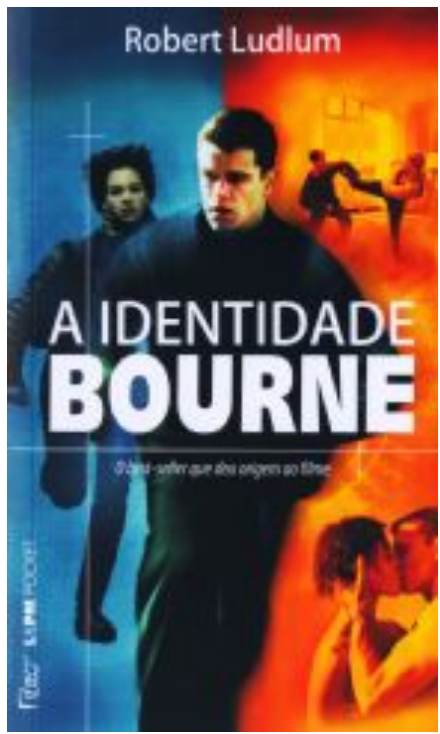

Fig. 12: Identidade bourne

A L\&PM também recorre pouco a trechos de críticas positivas na capa para legitimar as obras, defender suas qualidades e relacioná-las a obras e autores já consagrados e reconhecidos; um recurso comumente empregado em coleções que visam atingir um grande público. Contudo, insere, com frequência, esses pareceres na contracapa dos exemplares, permitindo, embora com menor destaque, a publicação de trechos mais longos e de mais de um crítico/autor.

Enquanto na capa encontramos, de modo geral, apenas o título e nome do autor, sem maiores detalhes que poderiam ser utilizados para divulgar a obra, na contracapa se concentram informações sobre o autor, a história e a coleção. Como a L\&PM Pocket possui diversas séries, nem todas seguem com exatidão a mesma estrutura para a contracapa, mas as diferenças são mínimas. Geralmente, a contracapa tem em sua parte superior, em vermelho e fonte maior que o texto restante, uma frase que pretende expor uma qualidade ou característica geral do livro, como, por exemplo, "uma das principais obras literárias do século XX" ou "poesia reunida". Logo após, já em tamanho menor e na cor preta, estão uma ou duas críticas/comentários, o resumo da obra e uma apresentação do autor. Por último, na parte inferior da capa, o logo da editora, a frase "a maior coleção de livros de bolso do Brasil", o aviso de que se trata de um "texto integral", destacado pelo uso da caixa alta e cor vermelha, mais uma caixa de texto vermelha com o conselho "Procure nas últimas páginas deste livro os lançamentos da Coleção L\&PM Pocket" na cor branca.

Como podemos observar, a contracapa aglutina diversas informações que poderiam ser divididas com a capa. Pela contracapa, o leitor percebe claramente que se trata de uma 
coleção de livros de bolso, é avisado que terá acesso a um "texto integral", como faziam diversas coleções similares da Europa e EUA para dissipar a crença de que é um texto resumido, comum no continente europeu durante séculos ${ }^{5}$, sendo a Bibliothèque Bleue o principal modelo, e é estimulado a consultar, nas últimas páginas, os lançamentos da "maior coleção de livros de bolso do Brasil”.

Atualmente, coleções de bolso internacionais, como as francesas Folio, da Gallimard, Points, da editora com o mesmo nome, as italianas Biblioteca Universale Rizzoli (BUR), da Rizzoli, Tascabili Bompiani, da Bompiani, entre inúmeras outras, não informam que a edição é integral. Parece que, em um mercado consolidado como o europeu, esta informação é desnecessária, não há mais a desconfiança da sociedade em relação à edição desses títulos em versões econômicas. Contudo, no Brasil, com o segmento ainda em expansão, cobrindo temas/assuntos que ainda não haviam sidos oferecidos em livros de bolso, esta informação pode ser importante para o comprador/leitor.

Quando se fala de livro acessível no país, muitos brasileiros ainda têm como referência as coleções infanto-juvenis que surgiram nas décadas de 1970 e 1980 e desde então são amplamente adotadas nas escolas. Uma das mais conhecidas, a coleção Reencontro, lançada em 1984 pela Scipione, é formada por clássicos nacionais e internacionais adaptados por autores brasileiros para o público adolescente. Outro exemplo, mais remoto, de coleção de livro de bolso vendida no Brasil que sofria intervenções para diminuir o tamanho do texto, foi a Edições Segredo, da Tecnoprint. Lançada no início da década de 1950, a coleção obteve sucesso, mas também ficou conhecida pela baixa qualidade do projeto editorial e dos materiais utilizados, como apontou Labanca (2009). A variedade de títulos e coleções que sugiram a partir do final da década de 1990 ainda é desconhecida por parte da população, principalmente por aquela que perdeu o hábito da leitura após o período escolar.

Se as principais séries de ficção da coleção L\&PM Pocket continuam crescendo desde o seu lançamento, o mesmo ocorre com as não ficcionais. A maior delas é a Encyclopaedia, com 45 títulos. Apesar de recente, iniciando-se em 2009, a série é bastante diversificada, incluindo temas que podem ser inseridos em diferentes campos do conhecimento. Sua proposta é similar à coleção francesa Que sais-je?, da Presses Universitaires de France (PUF) e às coleções brasileiras Primeiros passos, Tudo é história e Prisma, as duas primeiras da

\footnotetext{
${ }^{5}$ Obviamente que, ainda hoje, em diferentes países, existem títulos em versões abreviadas. Contudo, a expressão "texto integral" é utilizada mais para dissipar a ideia, reforçada ao longo da história por coleções de baixa qualidade, de que livros a baixo custo ou populares são fragmentados/ mal revisados/ mal traduzidos, do que para diferenciar essas obras de coleções atuais que, por serem destinadas a crianças ou a leitores iniciantes, são editadas para facilitar a leitura.
} 
Brasiliense e a terceira da Melhoramentos, apresentando uma introdução a diversos assuntos que também formam os títulos dos livros. Nesse sentido, o título Santos Dumont discorre sobre a história do famoso inventor, a obra Impressionismo analisa este movimento artístico e assim por diante.

Ainda que a série já tenha publicado um título de autores brasileiros, no caso, uma discussão sobre as teorias de Sigmund Freud pelos psicanalistas Edson Sousa e Paulo Endo, a maior parte é formada por traduções da coleção Que sais-je? e, em segundo lugar, da coleção Very Short Introductions, da Oxford University Press. Inclusive, quase todos os livros traduzidos da editora francesa mantêm até o mesmo o número de páginas, 128, utilizado como padrão pela Que sais-je?. Ambas as coleções internacionais propõem cobrir as mais diversas áreas de conhecimento, seja de humanas, biológicas e exatas, porém, a principal contribuição da Very Short Introductions para a L\&PM Pocket é o seu conjunto de livros de ciências. Pela editora brasileira, já foram oferecidos títulos como Teoria quântica, de John Polkinghorne, Relatividade, de Russell Stannard, Cérebro, de Michael O'Shea, entre outros.

Com o propósito de divulgação científica, os autores da série Encyclopaedia são pesquisadores renomados que assumem o empenho de explicar discussões complexas ao grande público e iniciantes. Deste modo, os livros não são muito extensos (em geral, os exemplares da série brasileira possuem entre 100 e 200 páginas) nem caros (entre R $\$ 14$ e R\$ 16). No caso da L\&PM Pocket, esta é a série que mais se aproxima do meio acadêmico. Portanto, podemos concluir que ainda não surgiu espaço na coleção para títulos com reflexões mais densas, voltadas para especialistas, pesquisadores ou estudantes com maiores conhecimentos.

Se a série foi inspirada em uma fórmula que faz sucesso no mundo há várias décadas, as capas da Encyclopaedia não são uma adaptação de modelos anteriores, mas uma criação do próprio editor e proprietário da L\&PM, Ivan Pinheiro Machado. Fazendo jus ao nome da série, suas capas imitam uma página de enciclopédia, com uma foto, título e a apresentação do verbete a ser analisado já com as primeiras linhas de sua definição. Assim sendo, o possível leitor já conhece a proposta da série pela capa e tem acesso a um pequeno texto que o ajuda a compreender o conteúdo a ser abordado. 


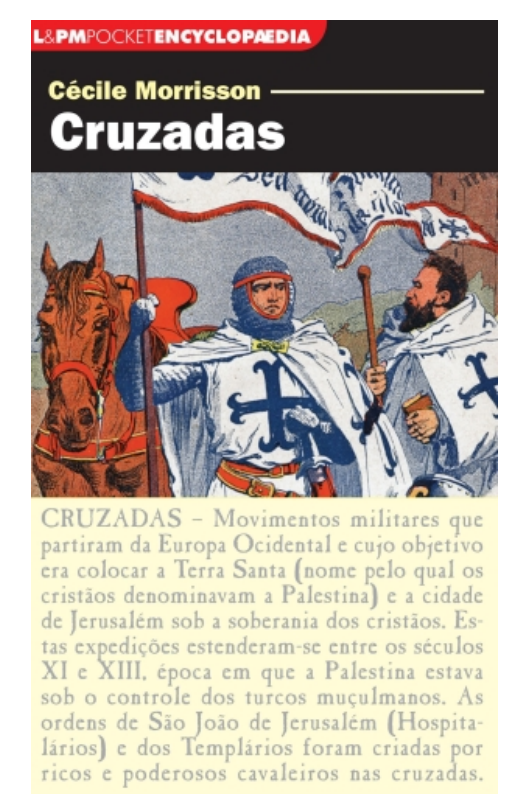

Fig. 13: Cruzadas

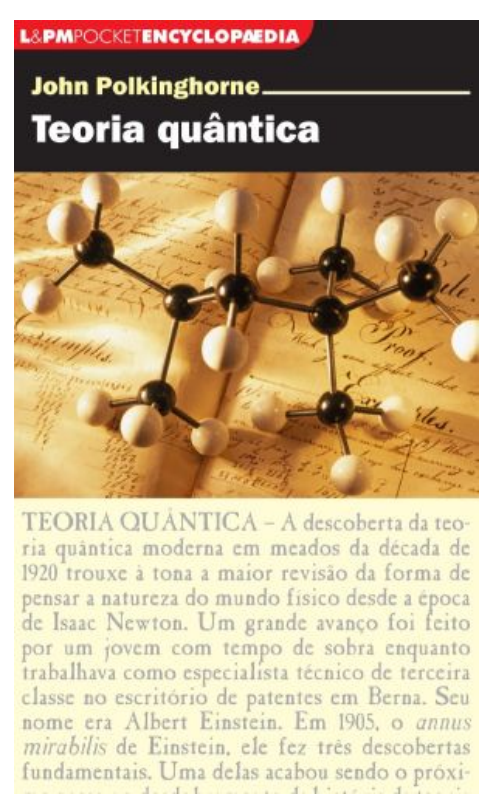

Fig. 14: Teoria quântica

$\mathrm{Na}$ França, foi no início do século XIX que surgiram as primeiras coleções enciclopédicas, recuperando o ideal das Luzes de tornar acessível o conhecimento científico e técnico. Em 1825, uma sociedade de estudiosos e pesquisadores lançou, no formato in-32, a coleção L'Encyplopédie portative ou Résumé universel des sciences, des lettres et des arts. De caráter popular, seu objetivo era oferecer uma visão geral da história de cada ciência/arte e ser útil tanto para professores como para aqueles que desejavam estudar por conta própria (OLIVERO, 1999, p. 170-171).

No mesmo período, também apareceram as primeiras coleções enciclopédicas voltadas para o ensino e aperfeiçoamento do trabalho dos operários, com a finalidade de divulgar conhecimentos “aplicáveis". A primeira produzida na França foi a Encyclopédie populaire, ou les sciences, les arts et les métiers mis à la portée de toutes classes, de 1828. A obra era uma versão nacional da Library of Useful Knowledge, lançada em 1827 na Inglaterra sob os cuidados da Sociedade pela Difusão do Conhecimento Útil - Society for The Diffusion of Useful Knowledge (OLIVERO, 1999, p. 171).

Os exemplares dessas coleções eram publicados periodicamente e a maioria era escrita por autores reconhecidos, seja pelo histórico acadêmico como pelo amplo saber em determinado ofício. Segundo Olivero (1999, p. 172), as enciclopédias populares criadas no século XIX estavam vinculadas a dois ideais: o primeiro, de difundir e vulgarizar o conhecimento ao maior número possível de pessoas e, o segundo, de moralizar e educar os menos escolarizados, especialmente artesões e operários, para melhor realizar suas atividades. 
No geral, a L\&PM pouco investe em capas abstratas. A maioria faz referência a uma cena da narrativa ou utiliza uma foto/pintura do autor. Como a editora publica muitos clássicos, o autor reconhecido torna-se uma estratégia de divulgação. O leitor pode se interessar pela obra porque é de um autor consagrado, referendado pela crítica, mesmo sem ter um conhecimento prévio da história ou das características de sua escrita.

Ao mesmo tempo em que a L\&PM também publica títulos contemporâneos, editar clássicos é uma ação recorrente em várias coleções de bolso pelo mundo, pois, como grande parte está em domínio público, é possível oferecer obras de qualidade, muitas delas já conhecidas pelos leitores, sem o custo extra dos direitos autorais. Como exemplo da relevância do nome do autor para a divulgação da coleção, a capa do catálogo L\&PM Pocket 2011 era formada pela junção de dezenas de capas com imagens de autores disponíveis na coleção.

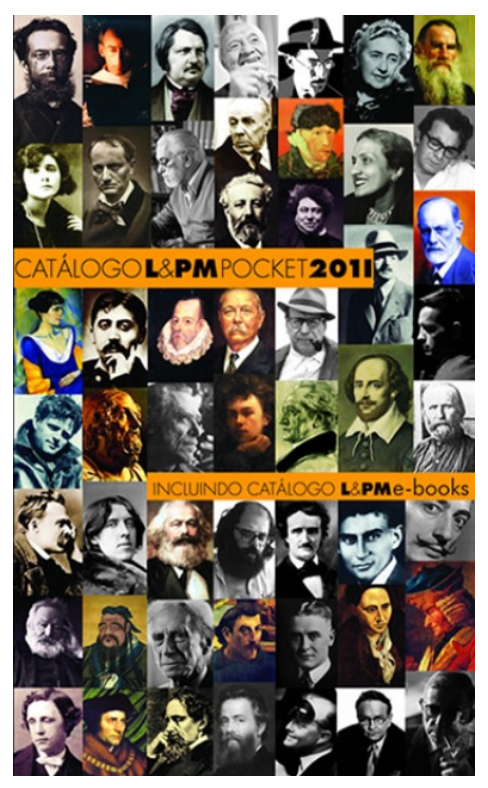

Fig. 15: Capa do Catálogo L\&PM Pocket 2011

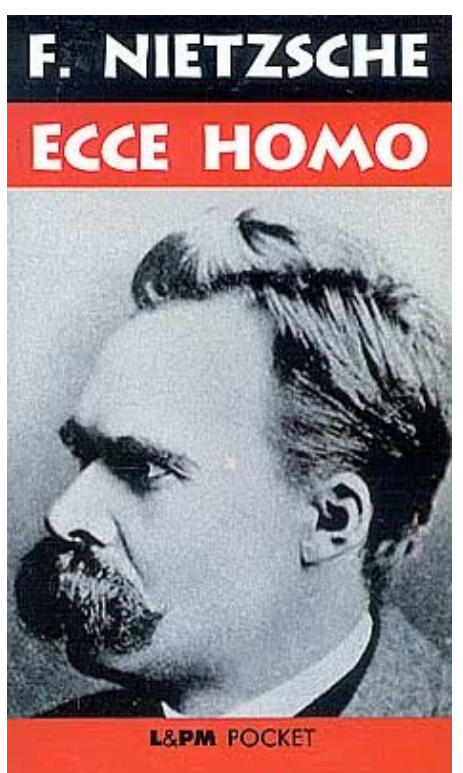

Fig. 16: Ecce Homo

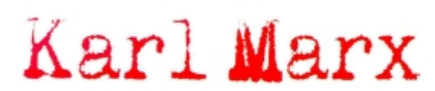

Liberdade de imprensa

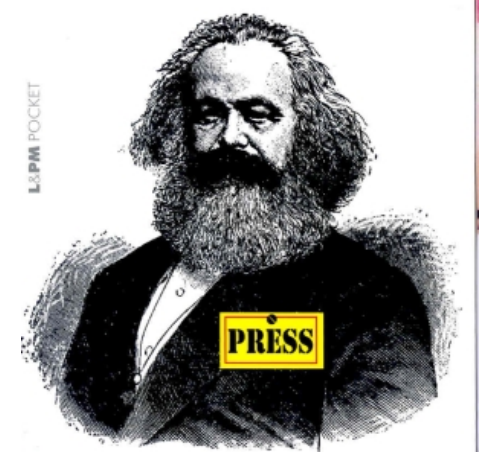

Fig. 17: Liberdade de imprensa 


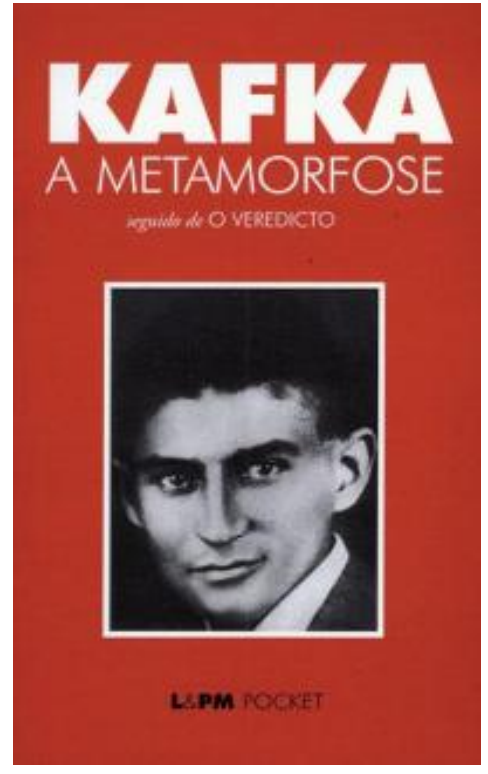

Fig. 18: A metamorfose

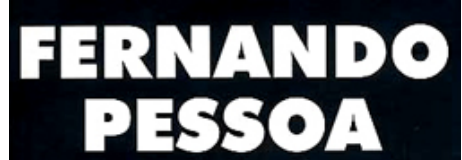

Obra poética III

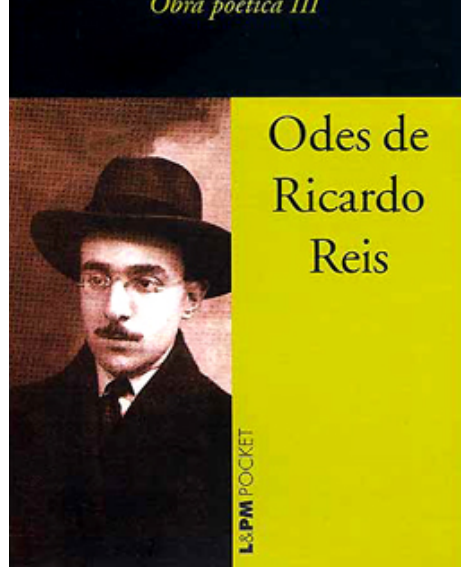

Fig. 19: Odes de Ricardo Reis

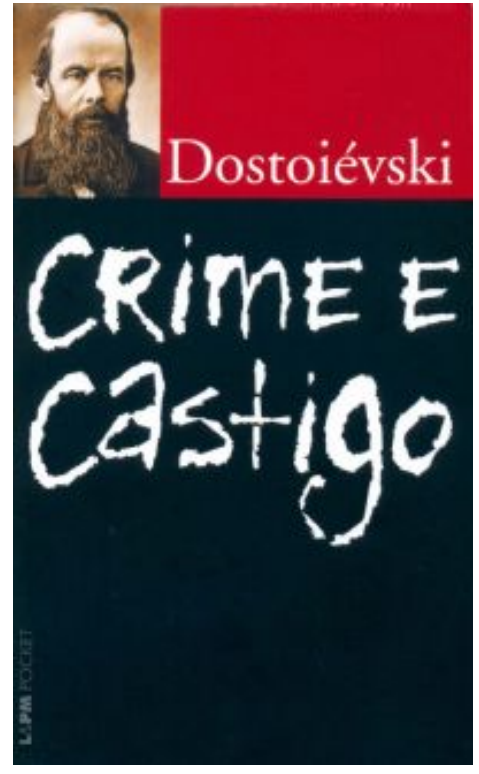

Fig. 20: Crime e castigo

Como citamos, em praticamente todo livro, uma pequena apresentação do autor é inserida na contracapa, semelhante ao que geralmente está disponível nas orelhas das edições em grande formato. Porém, quando se trata de clássicos, é frequente a vida e obra dos escritores também serem divulgadas nas primeiras páginas dos elementos pré-textuais, informando, em aproximadamente duas páginas, onde ele nasceu, estudou, morreu, suas principais obras e características. Com capas simples, utilizando apenas o título e a imagem do autor, como podemos observar acima, mais uma introdução biográfica nas páginas iniciais, os clássicos da L\&PM são organizados principalmente pelo reconhecimento autoral.

Os livros da coleção, em sua grande maioria, divulgam outros títulos do catálogo em suas páginas iniciais e finais. No verso da falsa folha de rosto são citados os demais títulos do autor assim como obras correlatas à venda pela editora. Já nas últimas páginas está disponível, em forma de lista, o catálogo da L\&PM Pocket, em sua totalidade ou os últimos lançamentos, esta última alternativa nos exemplares mais recentes. Em séries, como de Agatha Christie e Georges Simenon, após o catálogo geral, ainda pode ser apresentado, em forma de lista, todas as obras do autor. Por último, uma folha é opção para divulgar o lançamento de uma nova série, como a editora fez para a publicidade da Encyclopaedia.

Verificamos, a partir do exposto, que o atributo de coleção é reforçado em diversas oportunidades pela editora: na contracapa, com a propaganda "a maior coleção de livros de bolso do Brasil" e o pedido para consultar, nas últimas páginas, os demais títulos do catálogo. $\mathrm{Na}$ falsa folha de rosto, com a lista de títulos correlatos ao tema ou de outras publicações do autor. Na última folha, com informações do lançamento da série mais recente. Por fim, na 
lombada, com a numeração do livro indicando que ele está inserido em um conjunto muito maior. Desse modo, a obra é sempre oferecida a partir do lugar que ela ocupa na coleção, estimulando o leitor a entrar em contato com outros títulos.

Mesmo que não utilize capas chamativas, limite de páginas para evitar volumes muito extensos, ilustrações no interior do texto para "facilitar" sua compreensão, entre outras medidas já utilizadas ao longo da história para alcançar leitores menos instruídos ou sem o hábito da leitura, concluímos, pelo o exposto, que a coleção L\&PM busca ser amplamente acessível, consumida por todo tipo de leitor, do adolescente ao amante da literatura. Consequentemente, ela não publica séries de especialidades, voltadas unicamente para a academia, que poderiam ser adquiridas apenas por um público com conhecimentos prévios.

\section{Considerações finais}

Dos 1033 títulos da L\&PM Pocket analisados nesta pesquisa, quase 50\% custam entre R \$ 15,01 e R\$ 20. Entre os mais caros, somente 10 títulos ou $0,96 \%$ são vendidos por mais de R\$ 25,01. Se considerarmos os valores utilizados no mercado brasileiro para as coleções tradicionais, os livros da L\&PM Pocket são bastante acessíveis. Inclusive, algumas obras são oferecidas por R\$5, como é o caso da série 64 páginas, que, como o próprio nome sugere, são contos/novelas vendidos em exemplares de exatas 64 páginas. $\mathrm{Na}$ versão e-book, cada título da série tem o preço de $\mathrm{R} \$ 3$.

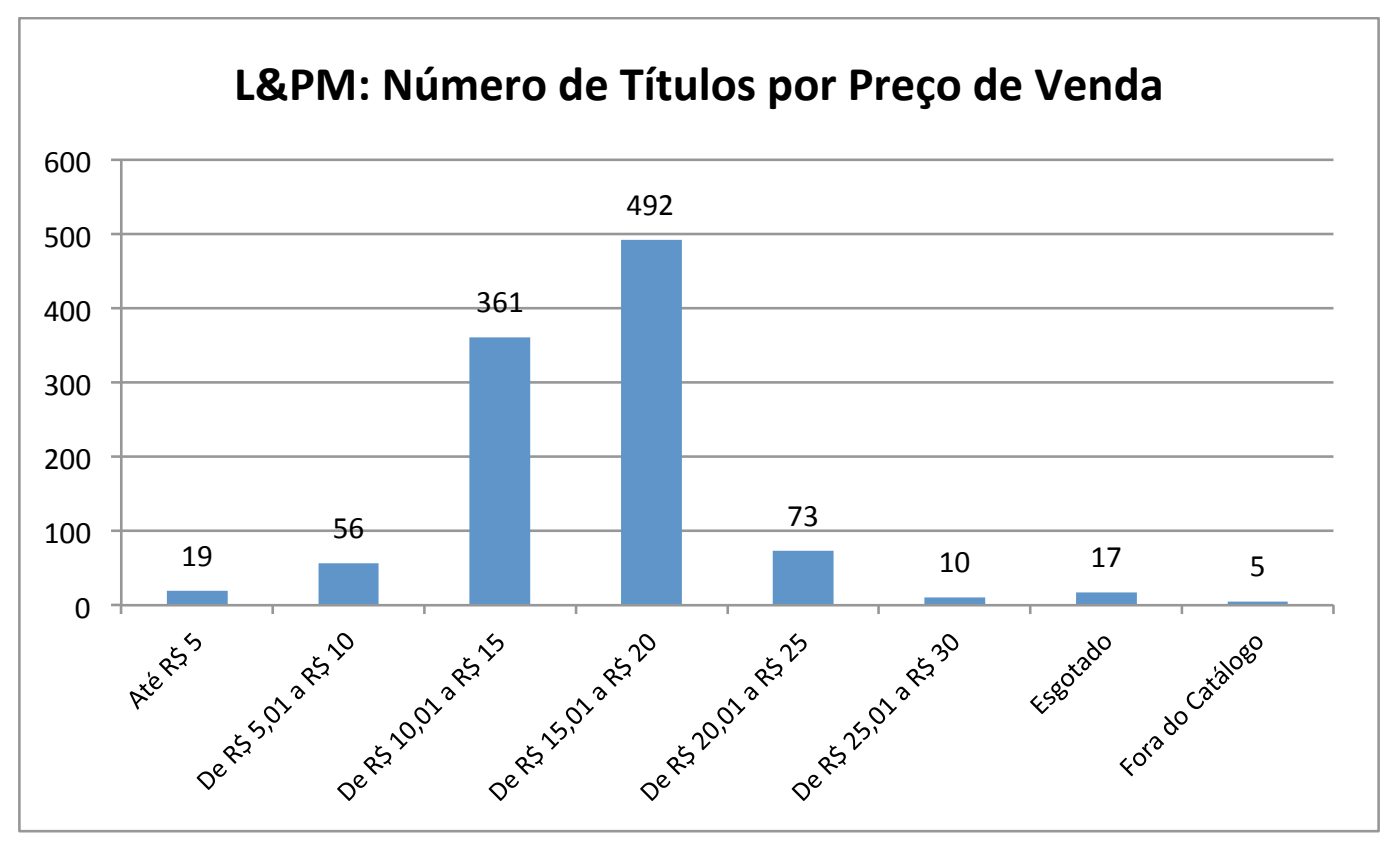

Tab. 1: L\&PM: Número de títulos por preço de venda 


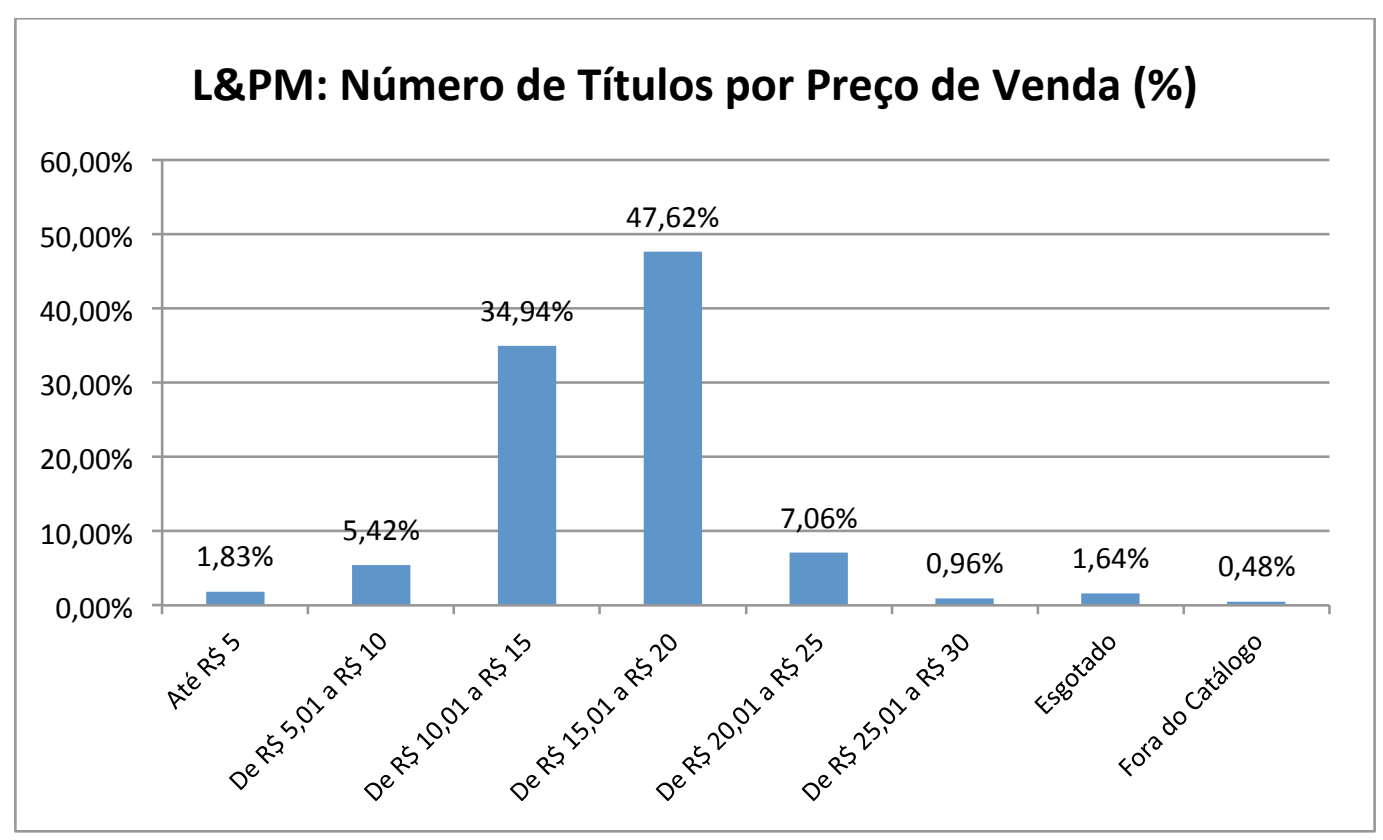

Tab. 2: L\&PM: Número de títulos por preço de venda (\%)

Em relação ao número de páginas, quase $72 \%$ dos títulos da coleção têm entre $101 \mathrm{e}$ 250 páginas. A editora pouco publica livros muitos extensos, apesar deles existirem. $\mathrm{O}$ Dicionário Caldas Aulete de Bolso, por exemplo, possui 1072 páginas; O romance Honra ou Vendetta, de Sílvio Lancellotti, 750 páginas. Em alguns casos, a decisão editorial foi por dividir uma obra em mais de um volume, apesar do número de páginas não parecer ter sido a razão para tal escolha: a poesia completa de Florbela Espanca foi dividida em dois volumes; o primeiro com 176 páginas e o segundo com 160. A poesia reunida de Affonso Romano de Sant'Anna, em volumes de 360 e 320 páginas, respectivamente. Os diários de Charles Darwin, organizados em Viagem de um naturalista ao redor do mundo, em volumes de 280 e 320 páginas, e assim por diante. Observa-se, portanto, que a maioria dos exemplares da coleção possui um número de páginas atraente/acessível ao leitor médio, em sintonia com a maior parte das publicações do mercado, enquanto os títulos mais extensos são raros ou divididos em mais de um volume. 


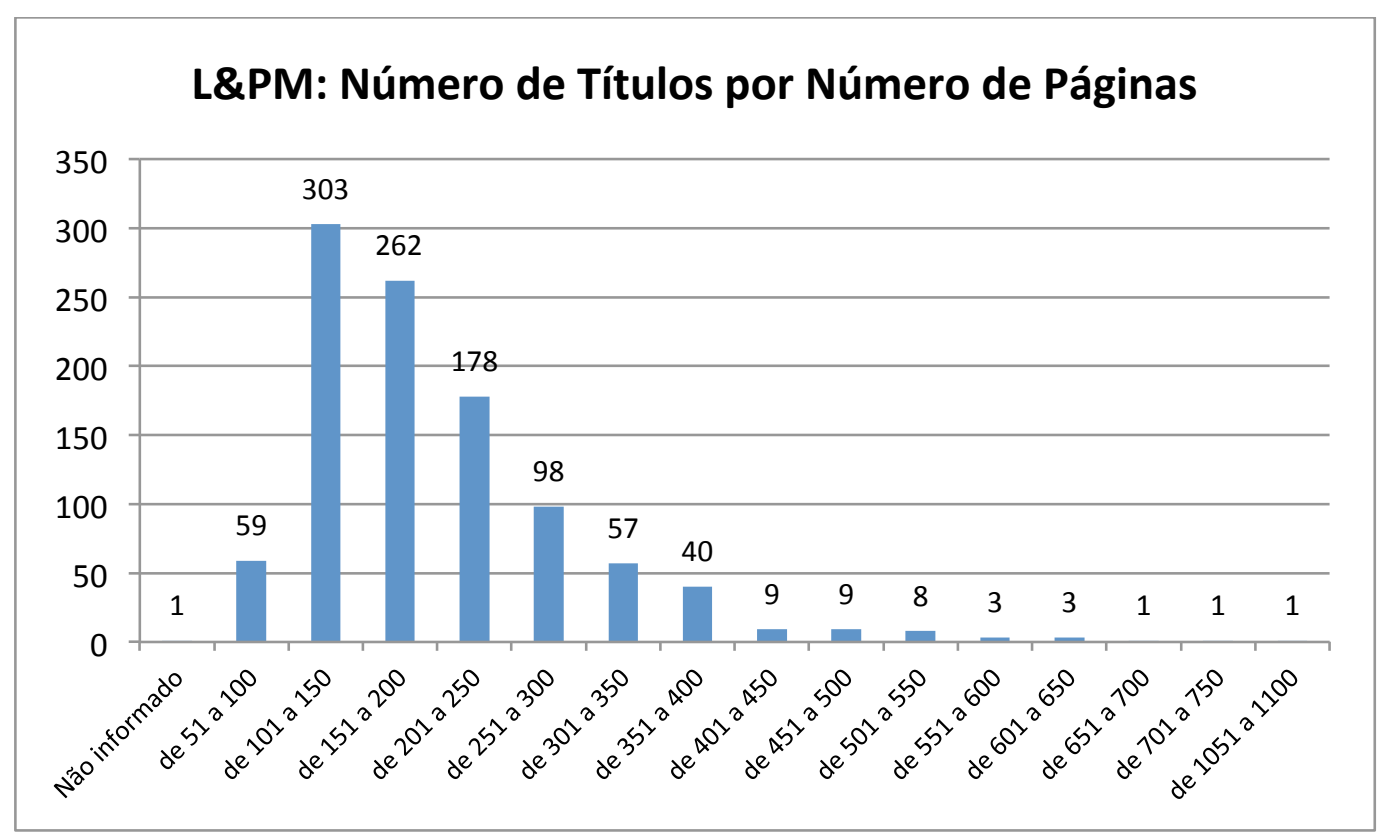

Tab. 3: L\&PM: Número de títulos por número de páginas

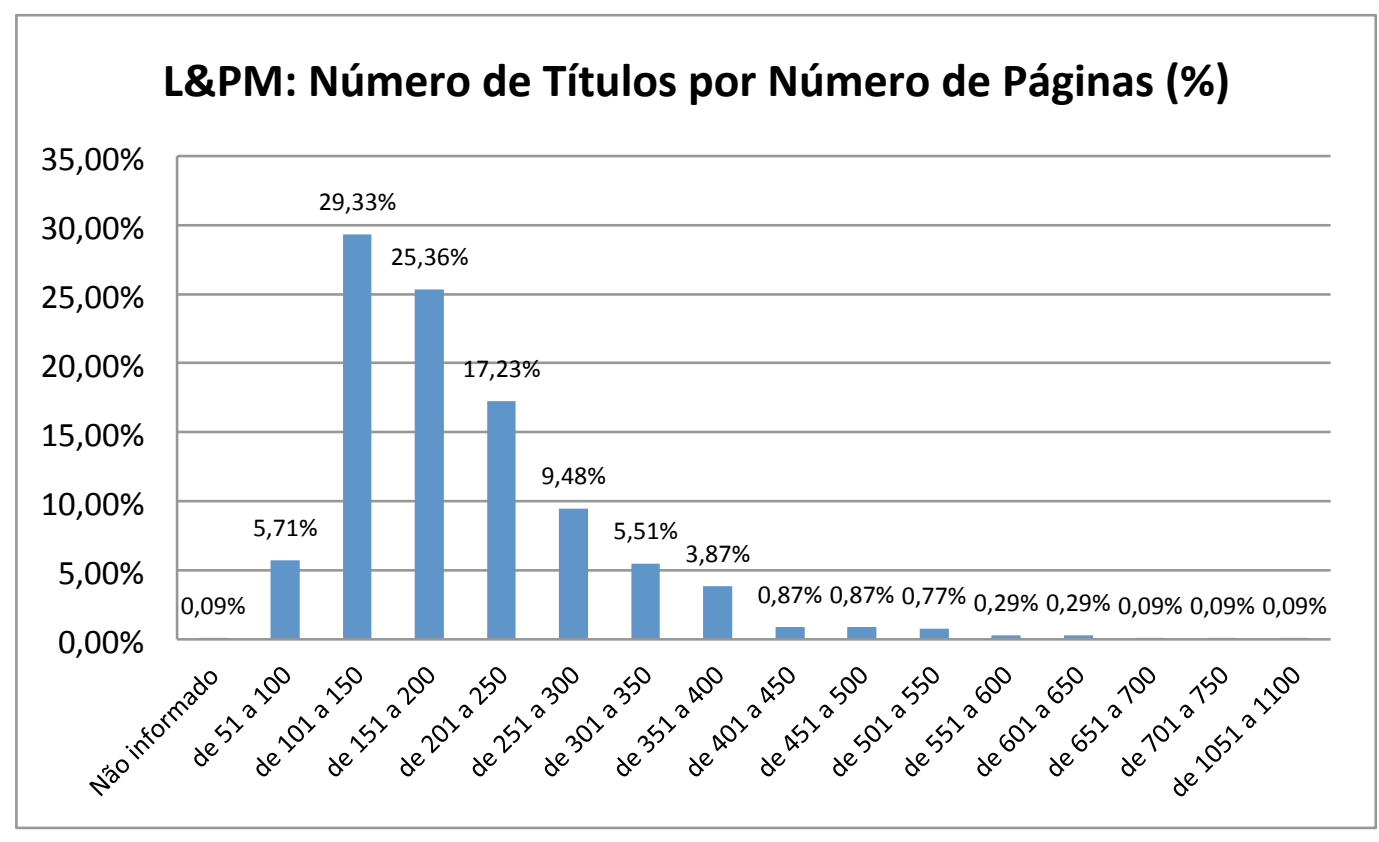

Tab. 4: L\&PM: Número de títulos por número de páginas (\%)

Os romances dominam o catálogo da coleção, ultrapassando $38 \%$ dos títulos. É nesta categoria que estão os romances policiais, incluindo as séries Agatha Christie e Simenon. Em seguida, com pouco mais de $11 \%$, temos os contos, de um mesmo autor ou coletâneas. Em terceiro lugar, o que não é comum para uma coleção de livros de bolso, conforme já discutimos, aparecem as histórias em quadrinhos. De modo geral, a coleção L\&PM Pocket é 
bastante heterogênea, com obras que podem agradar a diferentes estratos sociais, sem restrições por idade, classe econômica ou nível educacional.

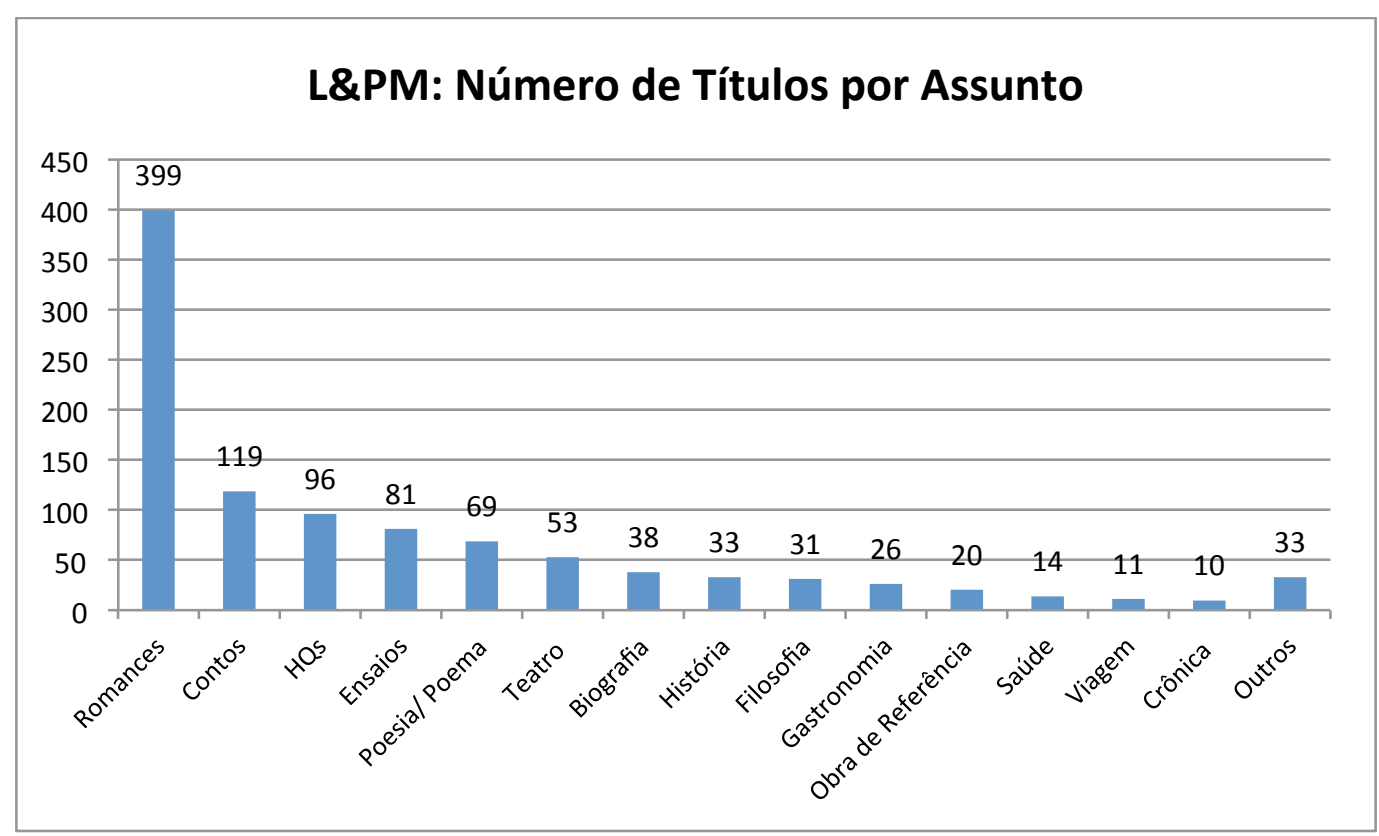

Tab. 5: L\&PM: Número de títulos por assunto

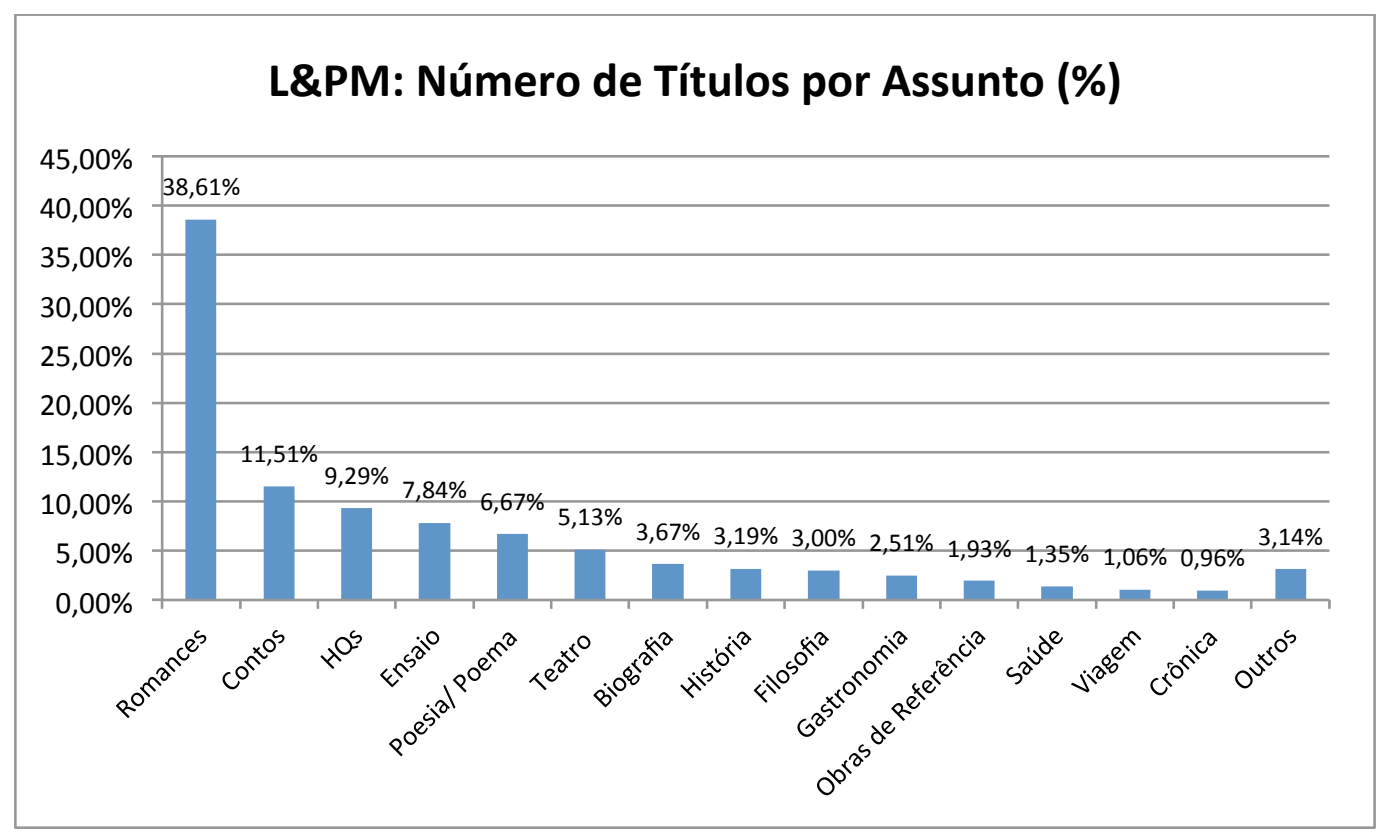

Tab. 6: L\&PM: Número de títulos por assunto (\%)

Ressalta-se, assim, que a coleção L\&PM Pocket é marcada pela diversidade de gêneros e séries, pelo preço acessível e pela constante atualização do seu catálogo, criando 
novas séries e acrescentando títulos as já existentes. Outra característica é que, apesar de ser uma coleção de bolso que pretende ser de baixo preço, suas publicações não se restringem a reedições de clássicos, obras em domínio público, mas mesclam autores contemporâneos e antigos, nacionais e estrangeiros. Com seu amplo catálogo, a L\&PM Pocket tem condições de agradar a diferentes leitores e oferecer seus títulos em diversos espaços de venda, dos mais tradicionais, como livrarias, aos emergentes, como supermercados. Contudo, por ser um catálogo generalista, que visa alcançar o maior número possível de leitores, ele não comtempla livros para especialistas de um campo do saber. Mesmo que cada série seja atrativa somente para um determinado grupo de leitores potenciais, o leitor-médio tem condições de lê-las sem a necessidade de ter frequentando uma universidade ou curso em particular. Alguns clássicos da literatura e ensaios filosóficos podem ser vistos como de maior complexidade por aqueles sem o hábito da leitura, porém, na maioria dos casos, um exemplar da L\&PM Pocket pode despertar o interesse tanto do frequentador da livraria como da banca de jornal ou do supermercado.

\section{Referências Bibliográficas}

AMORIM, Sônia Maria de. Em busca de um tempo perdido: edição de literatura traduzida pela Editora Globo (1930-1950). São Paulo: EDUSP; Com-Arte; Porto Alegre: Editora da Universidade/ UFRGS, 1999.

BOILEAU, Pierre; NARCEJAC, Thomas. O romance policial. São Paulo: Editora Ática, 1991.

L\&PM. Catálogo L\&PM Pocket. L\&PM: Porto Alegre, 2012. Disponível em: < http://www.lpm.com.br/catalogos/digitalbook/?Pocket2012 >. Acesso em: 15 maio 2013.

L\&PM. Entrevista com o capista de Agatha Christie. 2011. Disponível em: < http://www.lpm-blog.com.br/?p=10985 >. Acesso em: 03 maio 2013.

L\&PM. História. [2013?]. Disponível em:

$<$ http://www.lpm.com.br/site/default.asp?TroncoID $=805133 \&$ SecaoID $=845253 \&$ SubsecaoID $=384748>$. Acesso em 16 jan. 2013.

LABANCA, Gabriel Costa. Dos anos dourados às Edições de Ouro: a Tecnoprint e o livro de bolso no Brasil (1939-1970). 2009. 202 f. Dissertação (Mestrado em História)-

Universidade do Estado do Rio de Janeiro, Rio de Janeiro, 2009.

MACHADO, Cassiano Elek. Editoras líderes investem no bolso de leitor. Folha de S. Paulo, São Paulo, 14 abr. 2005. Disponível em:

$<$ http://www1.folha.uol.com.br/fsp/ilustrad/fq1404200506.htm $>$. Acesso em 30 ago. 2013.

OLIVEIRA, Livio Lima de. O livro de preço acessível no Brasil. 2002. 158f. Dissertação (Mestrado em Ciências da Comunicação)-Universidade de São Paulo, São Paulo, 2002. 
OLIVERO, Isabelle. L'invention de la collection: de la diffusion de la littérature et des savoirs à la formation du citoyen au XIX ${ }^{\mathrm{e}}$ siècle. Paris: Institut Mémoires de l'édition contemporaine ; Maison des sciences de l'Homme, 1999.

REIMÃO, Sandra Lúcia. O que é romance policial. São Paulo: Brasiliense, 1983.

TODOROV, Tzvetan. Tipologia do romance policial. IN: . As estruturas narrativas.

São Paulo: Editora Perspectiva, 1979. P. 93-104.

WILLER, Claudio. Ivan Pinheiro Machado: a leitura no Brasil e os pockets da L\&PM Editores. Agulha: Revista de Cultura, Fortaleza, São Paulo, n 65, set./out. 2008. Disponível em: $<$ http://www.revista.agulha.nom.br/ag65machado.htm>. Acesso em: 06 maio 2013.

Sites das editoras consultadas:

HAPERCOLLINS. Disponível em: < http://www.harpercollins.com >. Acesso em: 03 maio 2013.

L\&PM. Disponível em: < www.lpm.com.br > Acesso em: 03 maio 2013.

LE LIVRE DE POCHE. Disponível em: < http://www.livredepoche.com > Acesso em: 03 maio 2013.

PENGUIN. Disponível em: < http://www.penguin.co.uk >. Acesso em: 03 maio 2013.

Original enviado em: 21/09/2013

Aceito para publicação em: 22/11/2014

Sobre os autores

Willian Eduardo Righini de Souza

Mestre e Doutorando em Ciência da Informação pela Escola de

Comunicação e Artes da Universidade de São Paulo

Giulia Crippa

Professora Doutora do Curso de Ciências da Informação e Documentação da Faculdade de Filosofia, Ciências e Letras de Ribeirão Preto da Universidade de São Paulo e do Programa de Pósgraduação em Ciência da Informação da Universidade de São Paulo 